\title{
THE DIFFERENCE BETWEEN ARBITER IN THE ROMAN SENSE AND MODERN ARBITRATORS.
}

We find the word "arbitrium" first definitely employed as denoting the power of the ordinary judge (judex) to order the defendant to make specific restitution or performance. All decrees under the "formulary" system, dating from (c.) I87 A. D., being pecuniary, the only way of getting specific relief was to condemn the defendant in a penal or other sworn "nisi restituat." This power may perhaps have been termed "arbitrium" because it lay in the discretion of the praetor when drawing up the formula for the guidance of the judge, to insert in it this clause directing him to make an order ("jussus") for specific performance if he found the defendant liable on the facts. ${ }^{1}$

Next, we find the term arbitrium used in a somewhat similar sense in altogether a different class of cases. You will notice that in the case dealt with above, the formula is not quite absolute or positive. The praetor does not order the judge to condemn the defendant to pay, without qualification, if he finds him liable. $\mathrm{He}$ is only to pay "nisi restituat." Here we have clearly an absolute, positive, clear legal obligation: A has B's property. The judge, if he finds that to be the case, must give effect to B's legal right, only he must do it in this way, if the praetor in his discretion (arbitrium) inserts the "nisi restituat" clause: $i$. e., he must not condemn A out of hand,-but only if he declines to make specific satisfaction. In the case we are about to consider, the writer's contention is that we are no less in presence of an absolute and conclusive legal right, though for the reasons we shall now examine, the proceeding is nominally called

${ }^{1}$ Ortolan, "Instituts," t. III, Sec. I937. The writer is aware that Justinian (Inst. IV, 6, 3I) says that the action in this case got its name of arbitrario because it lay in the judge's "discretion" to allow the defendant the alternative of restitution. But it did not: the judge was rigidly bound by the formula. If the defendant restored, he must be absolved. It was reasonable that Justinian, legislating hundreds of years after the distinction between praetor and judex had ceased to exist, should fail to appreciate the point. Moyle thinks (Excursus X) that the name derives from the defendant's arbitrary "option" to restore the goods or submit to damages.

(732) 
an arbitrium and the judge an arbiter. The direction to condemn is qualified in this case as well as in the last; it is really not so greatly qualified, because, if the bench finds the facts against the defendant, it must pronounce some condemnation; there is no possibility of an absolution through defendant's compliance with an alternative. The qualification is, that the bench is not obliged to pronounce a hard and fast condemnation for a sum settled beforehand (or else to absolve); like a modern jury, it can give what damages it thinks fit. This end is secured by putting in the formula the words "ex fide. bona." The condemnatio is not "order A to pay $£ 500$ if you find him in the wrong," but "order A to pay what is properly due from him, if you find him in the wrong." Surely there is nothing in the world here suggestive of anything but the decision of a due legal claim. The formula "ex fide bona" was appropriate in almost every case of unliquidated damages; it was used, and it alone could be used, in all cases of claims arising out of bilateral contracts-every case of dispute about sales, taxes, partnerships, was tried in this way. Shall we say, therefore, that the Romans had no law of sale-but that it was left to the absolute taste and fancy of a casual arbiter to decide all cases. of sale by the light of nature? Such a proposition would be ridiculous. The arbiter decided according to law, and was bound so to decide. Only he was not bound to give the plaintiff a certain claimed sum, or nothing. He was at liberty, when he had applied the law to the facts, to say what the measure of damages was; and he had other valuable, but secondary, powers of doing justice between the parties, such as allowing set-off, dispensing with formalities and the like. For this reason Cicero styles the arbitrium "mite moderatum"; and so it is. The arbiter is not bound to repel the plaintiff from his claim because he thinks he has not put quite the right value on it. But no one has ever suggested that he was entitled to substitute his own ideas and fancies for the law, or to refuse the plaintiff his damages because he thought he had behaved badly. ${ }^{2}$

'Ort., op. cit., Sec. 1985. 
We find the two expressions "judex" and "arbiter" employed even before the advent of the formulary system,- but so indiscriminately, that Cicero says ${ }^{3}$ that it seems to him a remarkable thing that so many able men have so long applied their intellects to the matter without its ever yet being possible to say decidedly whether one ought to say "judex" or "arbiter" in any given case. If there were "arbiters" there might always be three of them (the Twelve Tables themselves say so, speaking from the remotest antiquity), whilst a judex must sit alone. Also, it is probable that an arbiter need not be a senator. And even the judex, as well as the arbiter, had to be agreed on by the parties to the litigation. Probably, in the later developed of the legis actiones (which preceded the formulary system) $-i$. e., in the judicis arbitrive postulatio, the bench was more often than not composed of arbiters. But the grand distinction, whether under the regime of the legis actiones, or of the formulary procedure which succeeded them, was that the judex in the sacramentum or the conditio certi was bound by a rigid direction to condemn in a certain amount, whilst the judex or the arbiter in the postulatio and the arbiter in the formulary system was only bound to condemn in a proper amount. ${ }^{4}$

The distinction is put by Cicero in the De Officiis ${ }^{5}$ perhaps better than in any of his professional orations. It resides in the fact that a judge or arbiter in a postulatio under the old procedure, and an arbiter under the formulary system, decided salva fide. Not arbitrarily. Not according to their private ideas. Not apart from legal considerations, but allowing weight to considerations of good faith, as distinguished from technicalities. In a sacramentum or a condictio, bad faith was no defense. Before arbiters, it was. Consequently they were enabled to award proper damages and were not limited to the dry question of whether A had pronounced certain traditional words, and gone through certain traditional actions, or not.

'Pro Murena, XII.

-Ort., op. cit., Sec. 187o.

'III, Io. 
But all international law is based on good faith. Every international court is a court of equity. We have reached the stage in international affairs, when the formulary system was replaced by the extraordinaire cognitio, and every action is an actio bonae fidei. This must be so, as international law is embodied in the conscience of the civilized world. The contention that an arbitrator ought to go outside that law, and apply his own ideas of morality would not be to imitate the arbiter and his arbitrium, both of which kept strictly to the law; it would be to sanction anarchy. If there were a code of obsolete and rigid written international law, then and then only would it be right to say that an arbitrator, in departing from it in favòr of what was universally thought stringently necessary, was a true successor of the arbiters.

The strict old Roman law recognized only unilateral obligations and property. Complex and reciprocal transactions, such as the bilateral contract of sale, were beyond its grasp. A new law arose to regulate them, and of this law the exponents were the arbiters. ${ }^{B}$ But it was as law that they expounded it, and not as a system of arbitrary accommodations. Had the old law not been exclusive and codified, and cramped by the forms of former traditional "actions," the divergence between judge and arbiter need never have arisen. The law was greater and wider than "the Law." But in our times the law of nations is one and indivisible. There is nothing to prevent arbitrators from applying it, and no excuse for their applying something different.

Dr. Hunter in his commentary on Roman law arrives at the conclusion that the terms "judex" and "arbiter," if not synonymous "varied but slightly," and adds- "Whatever the true explanation may be, we need not be surprised if the puzzle that, according to Cicero, baffled the erudition and ingenuity of the Republican jurisconsults, should be too much for us." By the time of Gaius ${ }^{7}$ the word judex was used for the judge in

- Cicero, De Officiis, 47.

'A. D. I7o, circa. 
bonae fidei actions; so that by this time the distinction was quite obliterated. $^{8}$

What is clear, is the distinction between actions stricti juris and actions bonae fidei, which distinction corresponds to nothing in international law; and it is equally clear that a judex could be appointed to try either, whilst an arbiter or arbiters could only be appointed to try the last. It is clear also that there was no difference in function that Cicero could detect. May it not possibly be, that the original difference was in qualification (the list of judges being a very select one), and that when bonae fidei actions were developed, it lay in the arbitrium of the praetor to refer the parties to such a litigation, at his discretion, to a judex or to a board of arbiters similar to the recuperatores with whom he already was familiar as praetor peregrinus?

It has been suggested that it is the praetor's arbitrium and not the judge's, which gives a real action for the restitution of property its name of an arbitrium; the praetor, in his arbitrary discretion, inserts a nisi restituat clause. This would accord with the idea that in the bonae fidei actions again, it is the praetor's arbitrium, the exercise of which makes the arbiter; the praetor decides again in his arbitrary discretion, to send the case to skilled assessors instead of (like a stricti juris action) to a judex.

It ought to be added that the action called a condictio incerti, although it was tried by a judge and according to all the strictness of the older law, admitted of, and indeed required, an estimation of damages by the judex. It is, as Ortolan remarks, a transitional stage in the progress from the condictio certi where there was nothing for the tribunal to do but to find the facts, and condemn or absolve accordingly, and the bonae fidei action, in which it applied the new and developed law.

Thomas Baty, D.C.L., LL.D.

Inner Temple, London.

'Gaius IV., 63. 